\title{
UDC [024-056.26]:378.6:62(477.54)NTU“KhPI"
}

\section{PALYEY T. L.}

Scientific and Technical Library, National Technical University "Kharkiv Polytechnic Institute", (Kharkiv, Ukraine), e-mail: tetyana.palyey@khpi.edu.ua

NOVOSOLOVA S. Y.

Scientific and Technical Library, National Technical University "Kharkiv Polytechnic Institute", (Kharkiv, Ukraine), e-mail: svetlana_k75@ukr.net

\section{INFORMATION SERVICE FOR USERS WITH SPECIAL EDUCATIONAL NEEDS}

Objective. The article is aimed at the analysis of the current problem of the higher educational institutions, namely the creation of favorable conditions for teaching students with special educational needs. Methods. Benchmarking - study and analysis of the experience of university libraries and other organizations. Formation of requirements for support of this category. Result. Creation of comprehensive assistance in learning and conditions conducive to the successful adaptation of students, their psychological rehabilitation and personal development in society. Therefore, one of the priority areas of libraries' work is adaptation to learning, library and information services for users with special needs, providing them with free access to information, exercising their rights to receive quality services. Conclusions. Creating a virtual information space, ensuring physical accessibility, staff training contributes to the effective implementation of the tasks and motivating this category of users to personal adaptation and learning.

Keywords: inclusion; special educational needs; library and information services; information services; art therapy in education

\section{Introduction}

High-quality prompt servicing of this user category is an urgent task of libraries. This is confirmed by legal documents, which emphasize the equal free rights of all citizens to library and information services, both in person and remotely. These are the following laws of Ukraine: On Libraries and Librarianship (Pro Biblioteky i Bibliotechnu Spravu, 1995), On Information (Pro Informatsiiu, 1992), On Education (Pro Osvitu, 2017) and the Decree of the President of Ukraine on Ensuring the Barrier-Free Space in Ukraine (Pro Zabezpechennia Stvorennia, 2020). Every year, on October 10, World Mental Health Day is celebrated. This event is aimed to draw public attention to the existing problem. Unfortunately, according to statistics, in the last 10 years, the number of people with special needs has doubled. This social category requires special attention.

In pre-school and secondary education institutions, the issue of social adaptation of children with special educational needs (SEN) is solved by having an educator/teacher assistant who helps with learning.

Having entered the higher educational institution, the student must independently adapt to new learning conditions in a new social environment.

An inclusive approach to the organization of the educational environment includes:

- adaptation,

- $\quad$ socialization,

- learning,

- $\quad$ education of users with special educational needs.

The main areas of preparation for working with users with SEN are the formation of virtual information space, ensuring physical accessibility, staff training. 


\section{Methods}

The experience of various organizations (including libraries) is used. This allowed us to formulate the requirements for servicing of readers with special educational needs. Internet technologies open up great opportunities for higher educational institutions and libraries to provide information to this category of users. The following measures are being implemented at the National Technical University "Kharkiv Polytechnic Institute":

- Education accessibility approved in the Admission Regulations to NTU "KhPI" (Pravyla Pryiomu, 2021).

- $\quad$ Creating conditions for physical access to educational buildings and infrastructure facilities is enshrined in the Procedure for Accompanying Persons with Disabilities and Other Low-Mobility Groups at NTU "KhPI": rules of communication and behavior (Poriadok Suprovodu, 2020). This document appoints the responsible persons, regulates the treatment rules of people with disabilities.

- $\quad$ Special programs and methods are being developed. For example: methods of teaching natural sciences to children with special needs (the method is described in the textbook "Inclusive education for hearing impaired people," which includes adapted practical classes in physics, chemistry, mathematics, telemedicine, geography, history).

- A virtual environment has been created, which includes: NTU "KhPI" corporate communication system based on Microsoft Office 365 services, distance learning system (DLS), the presence of the student's account for educational tasks.

NTU "KhPI" is one of the recognized leaders in Ukraine in the field of implementation of e-learning technologies in the educational process. With the support of the Kharkiv Regional State Administration, technical, methodological and organizational support is provided to students with disabilities (disabled people of groups 1-2). The Center for Distance Education of NTU "KhPI" is engaged in the practical implementation of information educational technologies in the educational process and conducts research in this area.

\section{Results and Discussion}

\section{Major fields of education:}

Formation of virtual information space.

Scientific and Technical Library of NTU "KhPI" is actively involved in the formation of a virtual information space for informing and communicating. For this purpose, the corporate communication system of NTU "KhPI" based on Microsoft Office 365 services is used:

- $\quad$ contacts of library staff are integrated into this system and are available to any user;

- Microsoft Office 365 services, such as shared calendar to inform users about events, chats, video records, etc. have been actively used. The Teams platform is used for remote classes in information culture and for cultural and educational events.

For example, the Microsoft Office 365 e-mail service (Outlook) makes it possible to use user groups formed according to various grounds and systemize information about all students and staff of the University. Search and informing are carried out by surname; academic group number; the name of the institute/faculty, department, subdivision, etc.

Previous library developments today can be used as the elements of a virtual environment. For example, a library site can be used as part of a personal virtual user environment (Figure 1). 


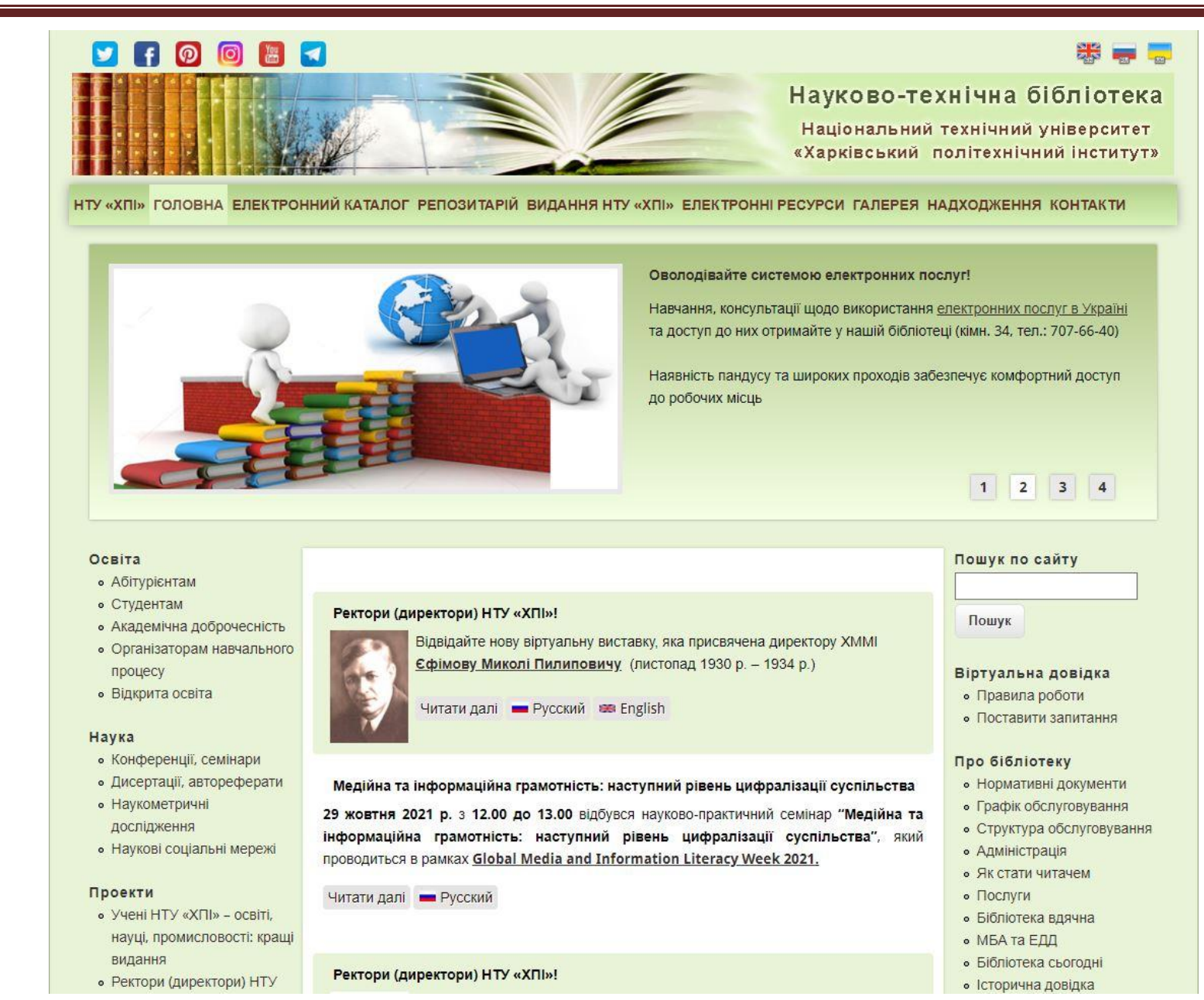

Fig. 1. Library site interface

The electronic catalog makes it possible to use bibliographic and full-text databases, provides access to the electronic library cards of the reader. The digital repository provides free access to the works of university scientists.

The Gallery section contains materials on the history of science and technology, our University, the personalities of prominent scientists, etc. These materials are used both for research purposes and expanding the overall worldview.

Reading is guided by the site sections Heart-Warming Books and Time to Read. Users are informed about the library interestingness and new acquisitions.

Ensuring physical accessibility.

The library is located in two buildings equipped according to the requirements of physical access of users with special educational needs. This makes it possible to receive services at any convenient service point in the shortest possible time. One of such points is the hall of reference books. The service area of the users is located on the ground floor, equipped with desktop computers, free Internet access (Wi-Fi) (Figure 2). 


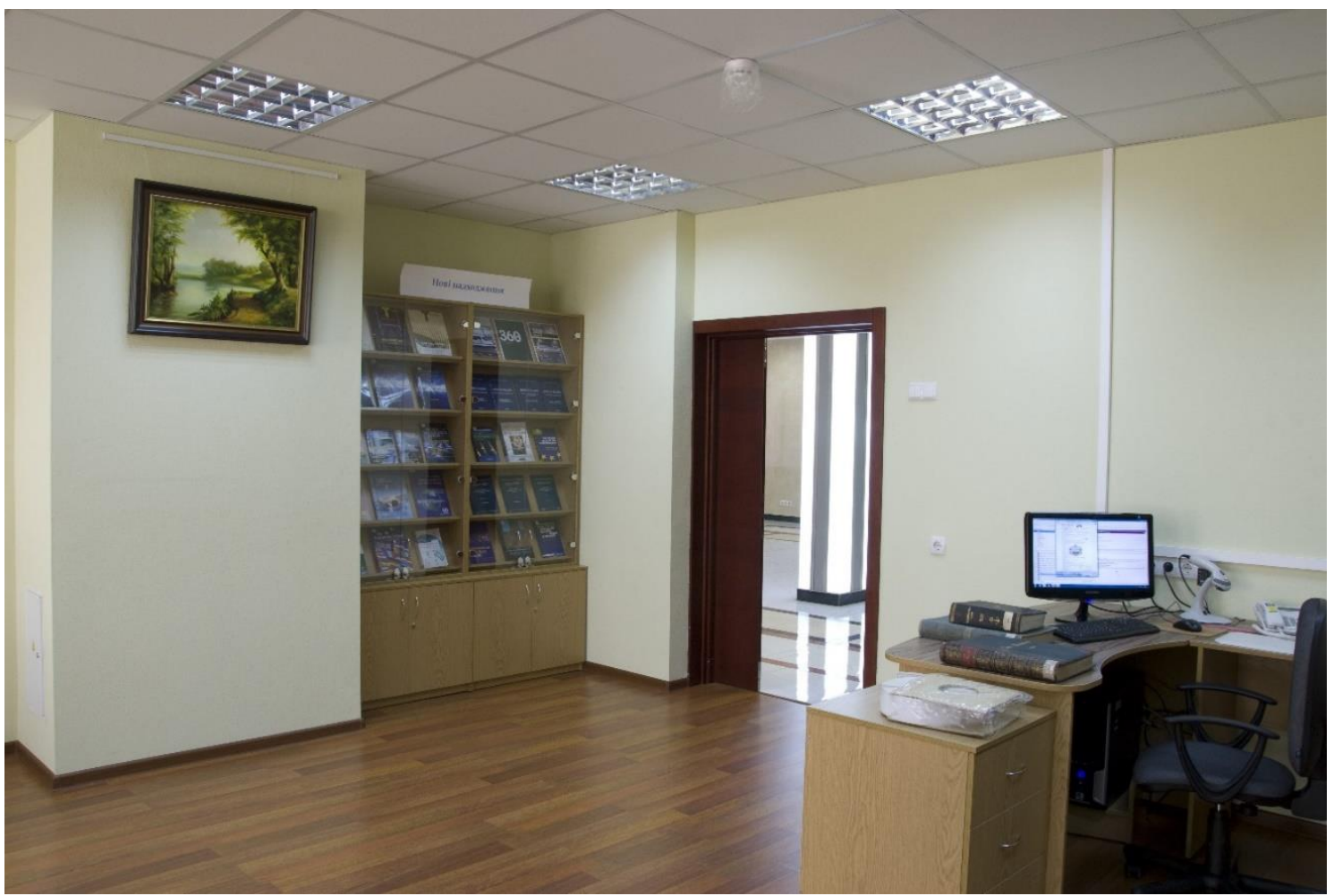

Fig. 2. Hall of reference publications

There is a leisure area for studying and recreation in the hall. Open publication viewings, interactive classes with students and other user categories are organized here. Mass events, art exhibitions and holidays are held in the free access zone. Such work contributes to the education and social adaptation of users with special educational needs (Figure 3).

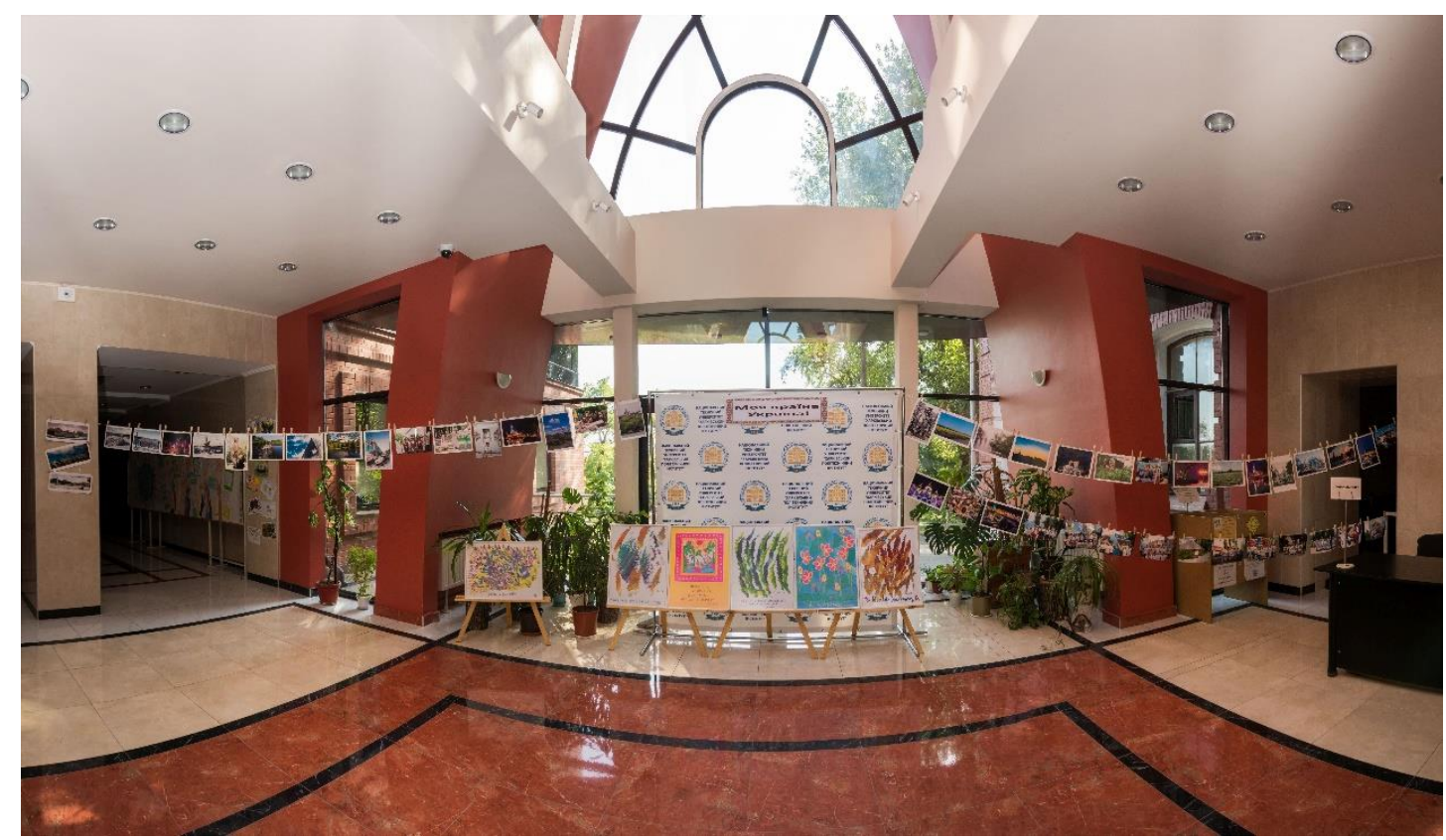

Fig. 3. Leisure area in the lobby of the scientific and technical library of NTU "KhPI" 
Staff training.

Staff training must meet the following criteria: Appropriate education, Inclusive competence, Readiness to work with the users with special educational needs, Use of domestic and foreign promising experience in organizing library services in this category (Novosolova, 2021a).

A team of specially trained specialists has been created in the scientific and technical library of NTU "KhPI." These are librarians who received the second higher education in the specialty: psychologists, high school teachers. We have a crisis psychologist, a practical psychologist, art therapist (rehabilitation specialist) in the service department. The library works closely with specialists of the Department of Pedagogy, Psychology, Management of Social Systems. Questionnaires, testing, application of art therapy techniques, emotional reset trainings are conducted jointly.

\section{Start of work.}

One of the areas of surveying users with SEN is to identify their needs and opportunities. Analysis of research has shown that more attention needs to be paid to adaptation and motivation to study. To solve this problem, a decision was made to create an Emotional reset room in the Scientific and Technical Library of NTU "KhPI." The purpose of this measure is to create a positive emotional mood, develop communication skills through information and bibliographic resources, bibliotherapy and other types of art therapy that promote skills development and adaptation in society.

The term "art therapy" defines a set of arts used in psychocorrection. The following functions of art therapy can be distinguished: diagnostic, therapeutic, humanistic. Isotherapy is one of the most developed areas of art therapy, which involves the use of pictorial tools and opportunities for personal development. Metaphorical Conceptual Maps (MCM) is a special type of art therapy based on the principles of projective methods. MCM is a set of pictures the size of a playing card or postcard depicting people, their interactions, life situations, etc. Art therapy helps users identify their needs and abilities, and we understand what information resources interest the reader. Art therapy methods allow revealing the possibilities and potential that contributes to the restoration of mental health (Kopytin \& Kort, 2011).

Today, the library plans to pay more attention to users with special educational needs, students, teachers and staff. The first steps in this direction include identifying people with special needs and creating a register of potential users who need specialized services. The register should include full name of a person with special needs, full name of his/her guardians, address, telephone, age, type of disease, abilities. While planning individual library services for this category of users, the marks in the reader's library card will help: the literature preferred, the range of the user's interests, the activity direction (Novosolova, $2021 \mathrm{~b}$ ).

To date, work has begun to identify the users with SEN among the students and staff of NTU "KhPI." 5 people gave their written consent to the receipt and use of personal information (Osnovy Zakonodavstva Ukrainy, 1992). According to the results of questionnaires, interviews, consultations, the range of hobbies, interests and wishes is revealed. It is planned to conduct stress tests, develop individual programs to help with learning, taking into account the personal needs and abilities, organize correctional classes aimed at developing cognitive processes: memory, imagination and thinking, engage users with SEN in the social environment, correct behavioral problems. 


\section{Conclusions}

The relevance of this topic is considered at the level of higher state bodies, which is reflected in the legislative framework. The library should ensure the development of quality services for people with disabilities.

It is necessary to ensure the formation of a virtual environment, physical accessibility, staff training. Due to the pandemic, the emphasis has shifted from providing a physical attendance to creating a personal virtual environment.

The measures will provide users with special educational needs with free access to any information, the realization of their rights to both general services and individual information services. Such work will help motivate these categories of users to study, social adaptation.

\section{REFERENCES}

Kopytin, A. I., \& Kort, B. (2011). Tekhniki telesno-oriyentirovannoy art-terapii. Moscow, Russia: Psikhoterapiya. Retrieved from https://www.twirpx.com/file/869492/ (in Russian)

Novosolova, S. Yu. (2021a). Efektyvnist metodu sposterezhennia pry vyiavlenni pozytyvnykh ta nehatyvnykh naslidkiv povedinky. Suchasni psykholohichni tendentsii pidtrymky ta vidnovlennia psykhichnoho zdorov'ia osobystosti: teoriia ta praktyka : II Mizhnar. mizhdystsypl. nauk.-prakt. konf., (24-25 veres. 2021 r., m. Kharkiv), 72-74. Retrieved from https://drive.google.com/file/d/1SkGcX6scpX4vIqIjV8JT8-5Ajvws0AFa (in Ukrainian)

Novosolova, S. Yu. (2021b). Formuvannia navychok u ditei z osoblyvymy osvitnimy problemamy. Inkliuzyvna osvita: ideia, stratehiia, rezultat : materialy I Vseukr. mizhdystsyp. nauk.-prakt. konf., (8 kvitnia 2021 r., m. Ternopil), 131-135. Retrieved from http://dspace.tnpu.edu.ua/bitstream/123456789/18577/3/inklyziv_conf_2021_novuj.pdf (in Ukrainian)

Osnovy zakonodavstva Ukrainy pro okhoronu zdorovia : zakon Ukrainy № 2801-XII. (1992). Retrieved from https://zakon.rada.gov.ua/laws/show/2801-12\#Text (in Ukrainian)

Poriadok suprovodu (nadannia dopomohy) osib z invalidnistiu ta inshykh malo mobilnykh hrup naselennia u Natsionalnomu tekhnichnomu universyteti «Kharkivskyi politekhnichnyi instytut». (2020). Retrieved from http://vstup.kpi.kharkov.ua/korisni-posilannya-dlya-abituriientiv/normatygnidokumenty/ (in Ukrainian)

Pravyla pryiomu do Natsionalnoho tekhnichnoho universytetu «Kharkivskyi politekhnichnyi instytut». (2021). Retrieved from http://vstup.kpi.kharkov.ua/admission/admission_rules/ (in Ukrainian)

Pro biblioteky I bibliotechnu spravu : zakon Ukrainy № 33/95-VR. (1995). Retrieved from https://zakon.rada.gov.ua/laws/show/32/95-\%D0\%B2\%D1\%80\#Text (in Ukrainian)

Pro informatsiiu: zakon Ukrainy № 2658-XII. (1992). Retrieved from https://zakon.rada.gov.ua/laws/show/2657-12\#Text (in Ukrainian)

Pro osvitu: zakon Ukrainy № 2145-VIII. (2017). Retrieved from https://zakon.rada.gov.ua/laws/show/2145-19\#n1235 (in Ukrainian)

Pro zabezpechennia stvorennia bezbar'iernoho prostoru v Ukraini : ukaz Prezydenta № 533/2020. (2020). Retrieved from https://zakon.rada.gov.ua/laws/show/533/2020\#Text (in Ukrainian) 
PALYEY T. L.

Науково-технічна бібліотека, Національний технічний університет «Харківський політехнічний інститут», (Харків, Україна), e-mail: tetyana.palyey@khpi.edu.ua NOVOSOLOVA S. Y.

Науково-технічна бібліотека, Національний технічний університет «Харківський політехнічний інститут», (Харків, Україна), e-mail: svetlana_k75@ukr.net

\section{ІНФОРМАЦІЙНЕ ОБСЛУГОВУВАННЯ КОРИСТУВАЧІВ З ОСОБЛИВИМИ ОСВІТНІМИ ПОТРЕБАМИ}

Мета. Аналіз актуальної проблеми ЗВО, а саме - створення сприятливих умов для навчання студентів 3 особливими освітніми потребами. Методика. Бенчмаркінг - вивчення та аналіз досвіду бібліотек університетів та інших організацій. Формування вимог до супроводу цієї категорії. Результатом має бути створення комплексної допомоги при навчанні та умов, що сприяють успішній адаптації студентів, їх психологічній реабілітації й особистісному становленню в соціумі. Тому, одним 3 пріоритетних напрямків роботи бібліотек є адаптація до навчання, бібліотечно-інформаційне обслуговування користувачів 3 особливими потребами, забезпечення їм вільного доступу до інформації, реалізації їх прав на отримання якісних послуг. Висновки. Створення віртуального інформаційного простору, забезпечення фізичної доступності, підготовка кадрів сприяють ефективній реалізації встановлених завдань і мотивації даної категорії користувачів до особистої адаптації та навчання.

Ключові слова: інклюзія; особливі освітні потреби; бібліотечно-інформаційне обслуговування; інформаційні послуги; арт-терапія в навчанні 